\title{
Recent fluctuations of glaciers in Valtellina (Italian Alps) and climatic variations
}

\author{
Manuela Pelfini \\ Dipartimento Scienze della Terra, Universitá, 20133 Milano, Italy \\ Claudio SMiraglia \\ Cattedra di Geografia, Universitátá " $D$ 'Annunzio", 65124 Pescara, Italy
}

\begin{abstract}
Valtellina, located in the Italian Alps of Lombardy, is extensively glaciated. Since 1925, terminal variations of the glaciers have been recorded. By analysing a significant sample of valley glaciers, we have recognized a rapid retreat of the termini which occurred between 1925 and the early 1970s. A period of advance followed, which stopped in the second half of the 1980s. The mean summertemperature fluctuations at the meteorological station of Sondrio at the centre of Valtellina, show that the period 1925-52 was very warm, and then the temperatures dropped. The most intense winter precipitation occurred in the period 1925-37. The behaviour of these glaciers is similar to that of other Alpine glaciers, although time of response may be different.
\end{abstract}

\section{INTRODUGTION}

Valtellina is a long longitudinal valley located on the Italian side of the Central Alps (Rhaetian Alps) in Lombardy. The latter is one of the most densely populated and industrialized regions of Italy, where farming is also intense. The presence of glaciers is very important in such an area because of both the possibility of electric power supply and tourism (Pelfini and others,
1989). Therefore, the analysis of recent fluctuations of the termini could be of the greatest importance. Valtellina is one of the most glaciated areas of the Italian Alps. According to the data of the World Glacier Inventory, there are 201 glaciers in Valtellina covering an area of $88.57 \mathrm{~km}^{2}$, which is $14.6 \%$ of the surface area of all Italian glaciers. The estimated water supply is about $2350 \times 10^{6} \mathrm{~m}^{3}$. The Bernina-Disgrazia (Mallero basin, $9.47 \mathrm{~km}^{2}$ and Lanterna basin, $26.23 \mathrm{~km}^{2}$ ) and the

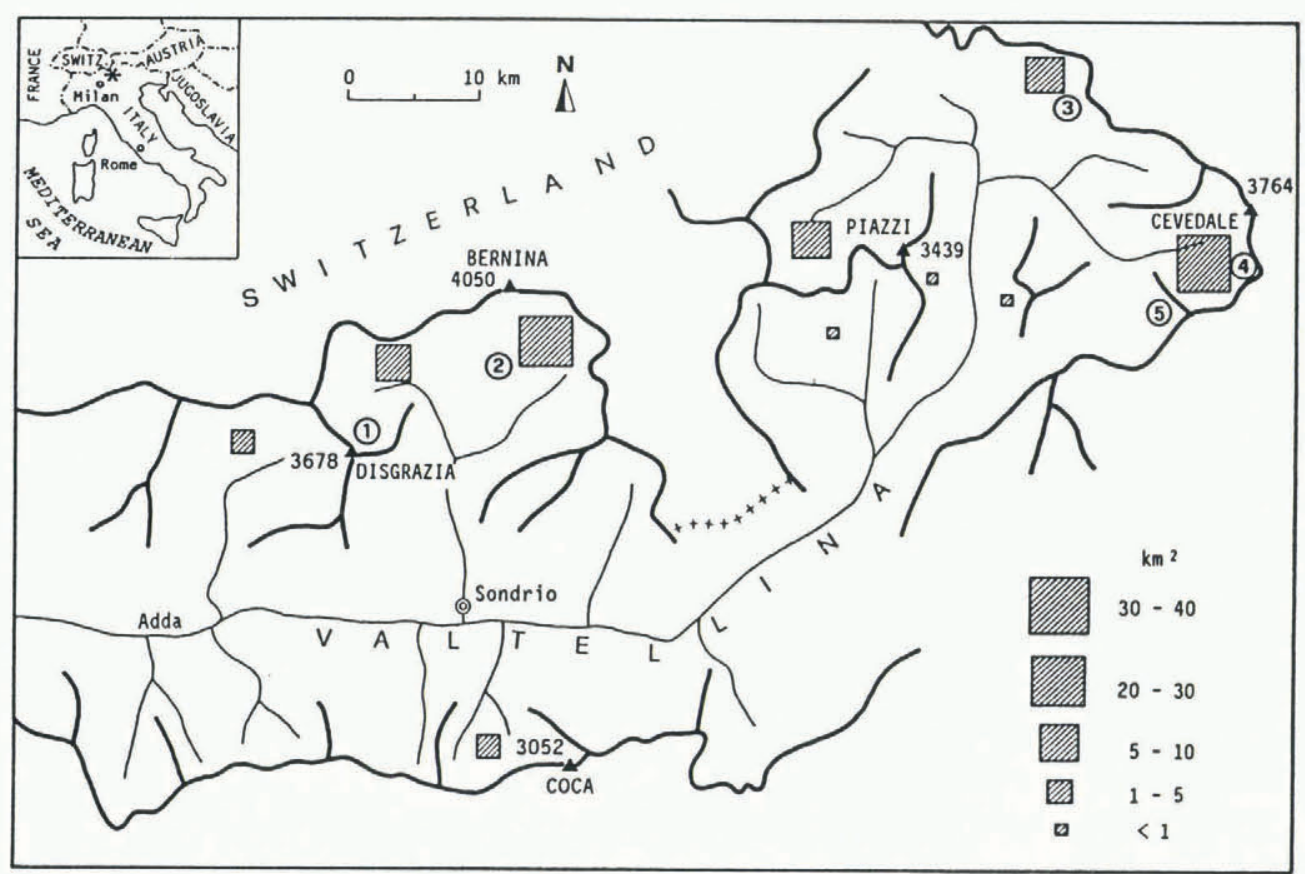

Fig. 1. Map showing Valtellina. Squares indicate classes of areas for the glaciers in individual basins. Numbers indicate the glaciers considered in the present study: (1) Ventina; (2) Fellaria; (3) Vitelli; (4) Forni; (5)Dosegù. 
Cevedale (Frodolfo basin, $36.26 \mathrm{~km}^{2}$ ) are the most glaciated mountain massifs (Fig. 1). Eight glaciers are classified as valley glaciers (among which, Ghiacciaio dei Forni alone has an area of $13 \mathrm{~km}^{2}$ and is the widest in the Italian Alps); 105 are mountain glaciers and 88 are glacierets and snowfields.

Since the 1920 s, direct measurements of termini fluctuations have been recorded for most glaciers of Valtellina. The objective of the present study is to synthesize the data of fluctuations of the Valtellina glaciers from 1925 up to 1990, analyze climatic variations, correlate these parameters and then make comparisons with fluctuations of glaciers in other parts of the Alps as well as with other mountain regions.

\section{GLACIER VARIATIONS}

Since 1925, the fluctuations of the termini of several glaciers of Valtellina have been systematically recorded with a maximum of 45 units in 1990. Continuous historical sequences only exist for about ten and mostly for valley glaciers of the Bernina-Disgrazia and Cevedale mountain groups. Taking into consideration both significance (based on geographic distribution, exposure, size and morphology) and continuity of the data, some glaciers have been chosen. In the period examined, they are representative for the behaviour of Valtellina glaciers, namely, Ghiacciaio di Fellaria and Ghiacciaio del Ventina in the Bernina-Disgrazia massif; Ghiacciaio dei Vitelli, Ghiacciaio dei Forni and Ghiacciaio del Dosegù in the Cevedale massif.

The variations of the termini of these glaciers, recorded by tape measurements and theodolite surveying, from 1925 to 1990, are shown in Figure 2. The curves are also similar for glaciers which belong to different mountain massifs.
Table 1. Correlation matrix variations of the termini 1925-90

\begin{tabular}{lllll} 
Forni & Vitelli & Dosegù & Ventina & Fellaria \\
& & & & \\
\hline & & & & \\
0.225 & 1.000 & 0.651 & 0.348 & 0.606 \\
0.353 & 0.651 & 1.000 & 0.456 & 0.589 \\
0.404 & 0.348 & 0.456 & 1.000 & 0.251 \\
0.267 & 0.606 & 0.589 & 0.251 & 1.000
\end{tabular}

In order to make a better comparison of the termini variations of the five glaciers from a statistics point of view, we calculated the correlation coefficients of the different series of data pertaining to the period 1925-90 (Table 1).

Table 1 shows that the oscillations of the terminus of Ghiacciaio del Dosegù correlate best with the others, then Vitelli, Fellaria and Ventina follow. Forni does not correlate well with the others, possibly because of its morphology and size. In fact, it alone can be classified as a compound basin-valley glacier; moreover, it is wider by far than the other glaciers considered. However, a similar behaviour for the five glaciers is confirmed. It is possible to recognize three phases for all the glaciers: (1) a long period of rapid recession, (2) a short period of minor advance, (3) a short period (up to the present day) of minor recession.

During the first phase, the termini of Dosegù, Forni (Fig. 3) and Ventina retreated about $950 \mathrm{~m}$ up to $1100 \mathrm{~m}$, while the Vitelli and Fellaria recessions were less. The retreat of the tongues goes along with a reduction in

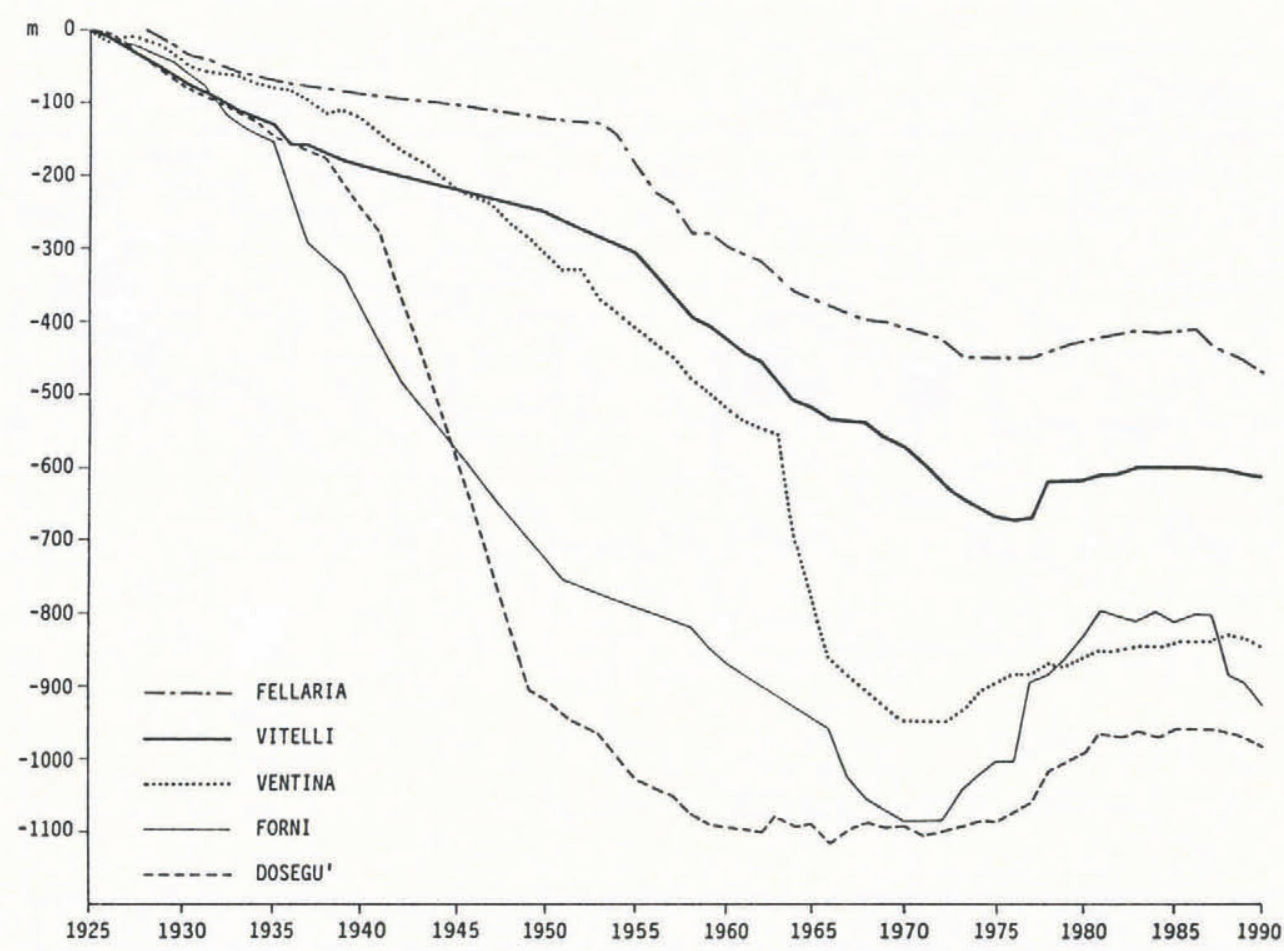

Fig. 2. Fluctuations of the termini of some Valtellina glaciers from 1925 to 1990. 


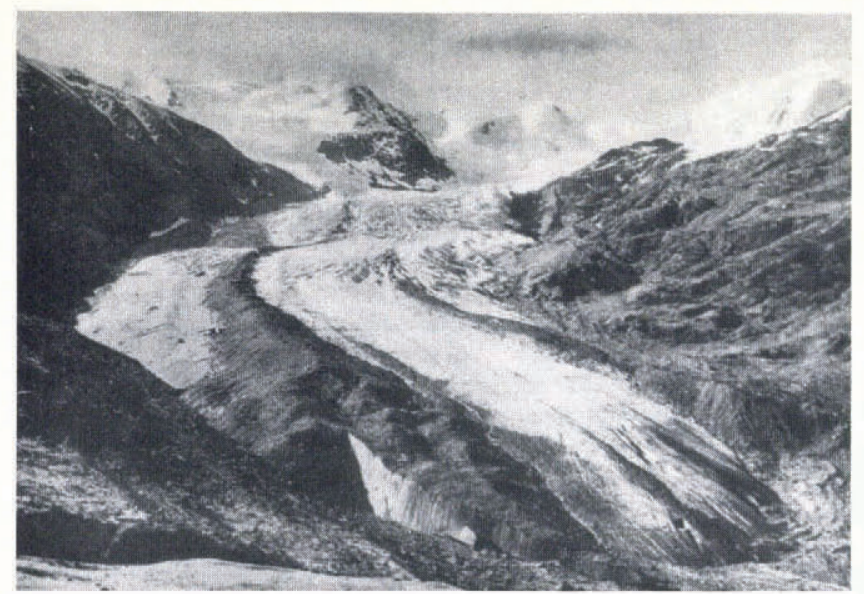

a

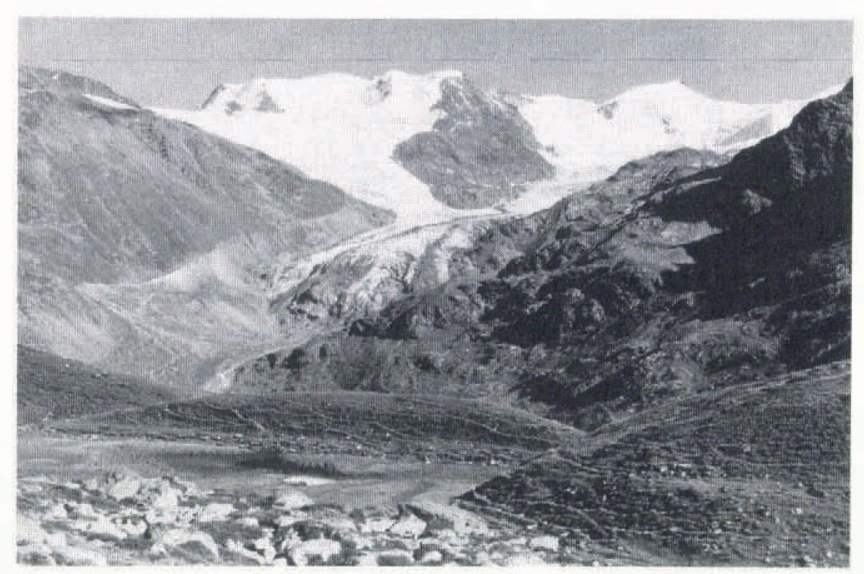

b

Fig. 3. Ghiacciaio dei Forni in the Cevedale massif at about 1910 (a) and in 1989 (b).

volume and fragmentation of the once contiguous glaciers. Ghiacciaio di Fellaria represents a good example: in the first decades of this century, it formed a large compound basin glacier on the southern side of the Pizzo Palù-Pizzo Zupò; after 1935, a division into two main parts with distinct termini occurred (Fellaria Occidentale and Fellaria Orientale; Nangeroni, 1954). From these tongues, the small glaciers of Pizzo Varuna and Cima Fontana, which is now a tiny snowfield, separated. The same trend can be observed in the large compound basin-valley glacier of the Bernina massif: Ghiacciaio di Scerscen, which at present consists of five mountain glaciers (Scerscen Inferiora, Scerscen Superiore, Marinelli, Caspoggio and Musella) (Fig. 4). Since 1926 , the great valley tongue of Scerscen retreated about $1000 \mathrm{~m}$ and reduced in thickness. In 1940, the two main ice fields separated (Belloni and others, 1988). This recent reduction of glacier masses in Valtellina fits the tendency towards recession that, in this area, had started soon after the "Little Ice Age", which culminated in 1850-60. This tendency was interrupted by two re-advances: one in 1870-80 and another, of minor importance, in the 1920s.

Field data, lichenometry, as well as historical sources, indicate that the Fellaria terminus had re-advanced with a maximum in 1890, then retreated substantially. In 1920, a minor re-advance occurred (Orombelli, 1987). As for Ghiacciaio dei Forni, the same phases occurred about 10 years later (Pelfini, 1988).

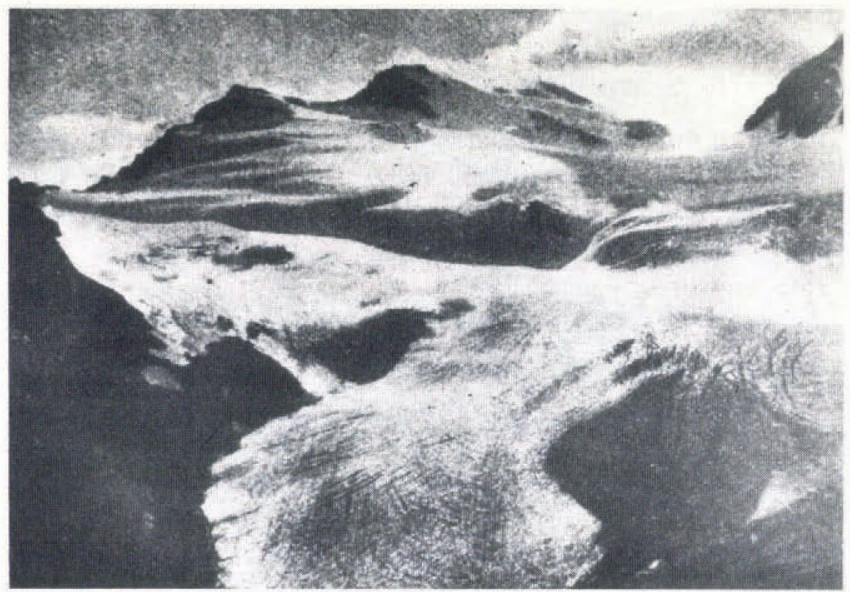

a

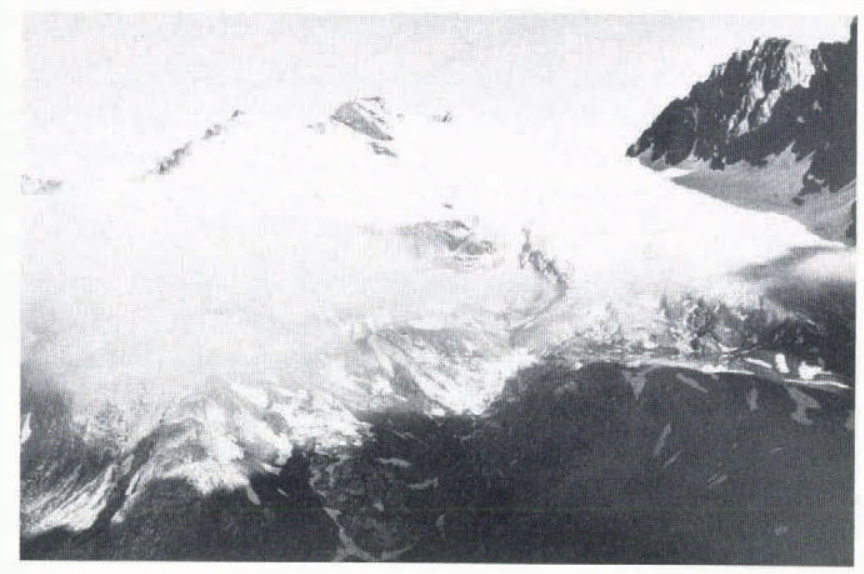

b

Fig. 4. Ghiacciaio di Scerscen in the Bernina massif in 1928 (a) and in 1988 (b).

With respect to the more recent fluctuations (cf. Fig. 2), a reversal of this trend has also occurred since 1962 for Dosegù, and since 1970 for Ventina and Forni. A few years later it occurred for the other two glaciers. There is a short period when the retreat of the termini of all the studied glaciers came to a halt and the measurements indicate stationary conditions.

A phase of advance followed which, starting from the 1970 s, involves all the glaciers of Valtellina. The valley glaciers advanced and equilibrium lines at elevations lower compared to those of preceding years could be observed. New moraines of limited height (1-2 m) indicate the maximum positions reached by the glaciers (Pelfini and Smiraglia, 1990). For most of the mountain glaciers located at high altitudes, it was difficult to identify the termini, which were covered with snow and firn and the snow line was below the glaciers. Snowfields formed again in cirques and valleys where glaciers had vanished for at least 20 years. As for the five glaciers examined, the Forni and Dosegù termini advanced respectively by 306 and $125 \mathrm{~m}$ between 1972 and 1981 . The Fellaria terminus advanced by $33 \mathrm{~m}$ between 1978 and 1983, while Vitelli advanced by $74 \mathrm{~m}$ (in the same period). Ventina terminus advanced by $116 \mathrm{~m}$ between 1973 and 1988. The data show that the glacier which has the maximum size, Ghiacciaio dei Forni, is the one which advanced the most. The trend of the curves shows that the expansion reached its culmination in a relatively short 


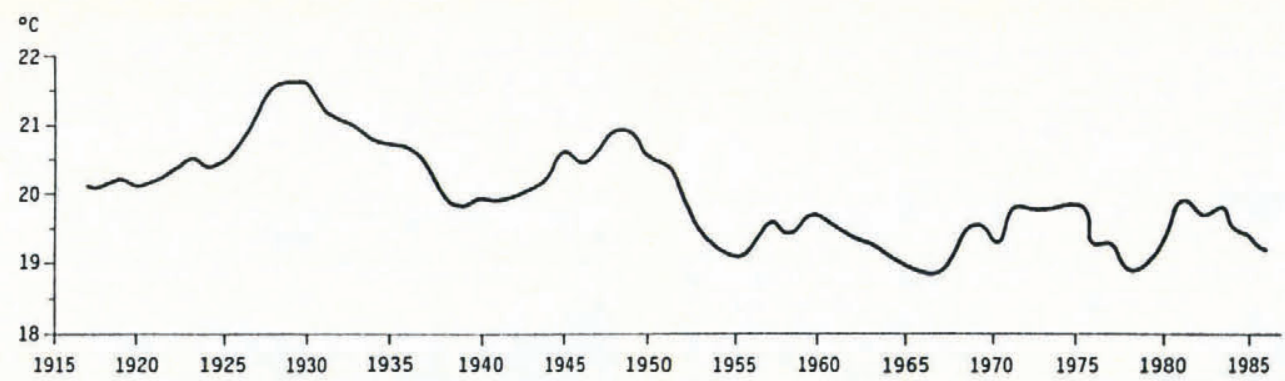

Fig. 5. Mean summer (June-September) temperatures (5year running means) recorded at Sondrio from 1917 to 1986.

time, with rapid annual advances (Ghiacciaio dei Forni reached a maximum of $111 \mathrm{~m}$ in 1977 , after 6 years since the beginning of the expansion; Ghiacciaio del Ventina showed a maximum advance of $27 \mathrm{~m}$ in 1973 after 3 years of being stationary). This advance has been followed by a renewed recession of the termini which is more rapid and intense for Ghiacciaio dei Forni (after a period of fluctuations, a retreat of $96 \mathrm{~m}$ occurred between 1987 and 1990).

This latter phase can be observed in all the other glaciers of Valtellina. In addition to a reduction in length, the equilibrium line rises in altitude (during the summers of 1988 and 1989 the AAR factor for some glaciers was very small). Furthermore, thinning of the termini, as well as extinction of a great number of glacierets, was observed.

\section{CLIMATIC OBSERVATIONS}

Several meteorological stations are located in Valtellina, a great number of which do not have a sufficient record of data. Some previous works (Belloni and others, 1985, 1990) demonstrated that the station of Sondrio is representative for climatic variations in the whole region and, in particular, temperature variations. Even though located at the bottom of the valley, at an elevation of $298 \mathrm{~m}$, Sondrio has a central position with respect to the glaciers of Valtellina which are at a distance of a few tens of kilometers.

The mean summer (June-September) temperatures recorded at Sondrio station between 1915 and 1988 have been used in the present study. Figure 5 shows 5 year running means of this series. From the diagram, it can be seen that from 1917 to 1952 temperatures are constantly higher with respect to those of the following years. Two particularly warm periods occurred between 1925 and 1935 and between 1945 and 1951. As a whole, the period 1925-52 can be considered exceptionally warm. From Figure 2, it is possible to observe that during this period all the glacier termini retreated. Temperatures sank both in the middle of the 1950s and in the second half of the 1970s. The advance of the glaciers started at the beginning of the 1970 s.

The reduced expansion and renewed retreat of the termini, which almost corresponds to a rise in temperature, occurred in the early 1980s.

With regard to precipitation, the mean winter (October-May) precipitation recorded at Sondrio station is shown in Figure 6. It can be seen that the most intense precipitation occurred between 1925 and 1937, just during the warmest phase. A second short period of intense precipitation can be observed from 1975 to 1980 , when summer temperatures were lower.

\section{CONCLUSIONS}

Valtellina glaciers show a long and rapid retreat which started in 1925 and represents the response to the very warm, although in part wet, period between 1925 and 1952. This phase came to a halt at the beginning of the 1970 s, when the termini started to advance, about 20 years after the beginning of a period characterized by lower summer temperatures. These same events, although showing different times of response, have been observed in the whole of the Italian Alps (Zanon, 1985; Pelfini and Smiraglia, 1988) and fit into a general scenario. The massive reduction of the glacier volume in the mountain chains which followed the "Little Ice Age" is, in fact, a worldwide phenomenon (Haeberli and others, 1989). The slackening of the phase of retreat as well as the subsequent expansion of the glaciers, starting from the beginning of the 1970s, is also well documented, particularly in the Alpine chain (Patzelt, 1985; Makarevich and Rototayeva, 1986).

Valtellina glaciers may be considered good indicators of climatic trends of our century. Because of their practical importance in a region such as Lombardy, it is necessary to carry out further studies, especially regarding the relationships between climatic parameters (temperature as well as rainfall) and the fluctuations of the volumes of the glaciers.

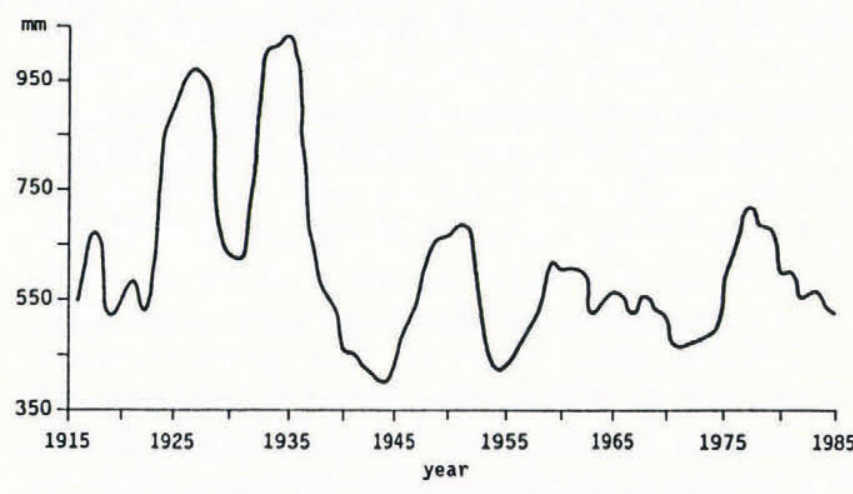

Fig. 6. Mean October-May precipitation (5year running means) recorded at Sondrio from 1914 to 1987. 


\section{ACKNOWLEDGEMENTS}

The present study benefited from the contribution of the Italian Ministry of University, Science and Technology Research (MURST 60\%) and of the National Research Committee (CNR).

\section{REFERENCES}

Belloni, S., G. Catasta and C. Smiraglia. 1985. Parametri climatici e oscillazioni frontali dei ghiacciai italiani nell'ultimo sessantennio. Mem. Soc. Geogr. Ital., 39, 169193.

Belloni, S., G. Catasta and C. Smiraglia. 1988. Un sessantennio di variazioni dei ghiacciai italiani. Il Bollettino - Ann. Comit. Sci. Club Alp. Ital. 87, 65-75.

Belloni, S., M. Pelfini and C. Smiraglia. 1990. Oscillazioni frontali recenti dei ghiacciai e variazioni climatiche: Valtellina, un approccio metodologico. Mem. Soc. Geogr. Ital., 46, 167-182.

Haeberli, W., P. Müller, P. Alean and H. Bösch. 1989. Glacier changes following the Little Ice Age - a survey of the international data basis and its perspectives. In Oerlemans, J., ed. Proceedings of the Symposium on Glacier Fluctuations and Climatic Change, held in Amsterdam, 1-5 June 1987. Dordrecht, Kluwer Academic Publishers, 77-101.

Makarevich, K. G. and O.V. Rototayeva. 1986. Sovremennyye klebaniya gornykh lednikov severnogo polushchariya [Present-day fluctuations of mountain glaciers in the Northern Hemisphere]. Materialy
Glyatsiologicheskikh Issledovaniy 57, 157-163.

Nangeroni, G. 1954. Appunti per una revisione del catalogo dei ghiacciai lombardi. Atti Soc. Ital. Sci. Nat., 93(3-4), 373-407.

Orombelli, G. 1987. Aspetti morfologici e paleoglaciologici della Valmalenco. In Valmalenco. Natura-1. Sondrio, 199-204.

Patzelt, G. 1985. The period of glacier advances in the Alps, 1965 to 1980. Gletscherkd. Glazialgeol., 21, 403407.

Pelfini, M. 1988. Contributo alla conoscenza delle fluttuazioni oloceniche del Ghiacciaio dei Forni (Gruppo Ortles-Cevedale, Sondrio). Nat. Bresciana, 24, 237-257.

Pelfini, M. and C. Smiraglia. 1988. L'evoluzione recente del glacialismo sulle Alpi Italiane: strumenti e temi di ricerca. Boll. Soc. Geogr. It., 11(5), 127-154.

Pelfini, M. and C. Smiraglia. 1990. Le morene di neoformazione del Ghiacciaio della Sforzellina (Gruppo del Cevedale, Alpi Lombarde). Riv. Geogr. Ital., 97, 59-75.

Pelfini, M., C. Smiraglia and C. Voltolini. 1989. Il glacialismo attuale delle Alpi Lombarde: conoscenza e utilizzazione di un particolare bene naturale. In Di Blasi, A., ed. L'Italia che cambia. Il contributo della geografia. Catania, 479-490.

Zanon, G. 1985. L'attuale tendenza evolutiva dei ghiacciai delle Alpi Italiane. Geogr. Fis. Din. Quat., 8(2), 89-96.

The accuracy of references in the text and in this list is the responsibility of the authors, to whom queries should be addressed. 